\title{
Endoneurial localisation of microvascular damage in human diabetic neuropathy
}

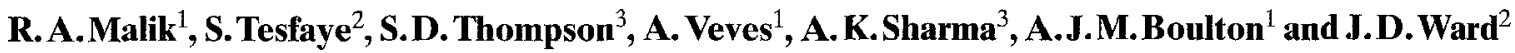 \\ ${ }^{1}$ Department of Medicine, Manchester Royal Infirmary, Manchester, UK \\ ${ }^{2}$ Diabetes Unit, Royal Hallamshire Hospital, Sheffield, UK \\ ${ }^{3}$ Department of Anatomy, University of Aberdeen, Aberdeen, UK
}

\begin{abstract}
Summary. Twenty diabetic patients with neuropathy underwent clinical and neurophysiological evaluation together with a detailed morphometric assessment of capillary pathology in endoneurial and epineurial microvascular beds of the sural nerve. Morphological data were compared with ten non-diabetic control subjects. There were no significant differences in control subjects between basement membrane area, endothelial cell area, endothelial cell profile number or luminal area of endoneurial when compared with epineurial capillaries. In contrast, when compared with epineurial capillaries, endoneurial capillaries from diabetic patients demonstrated a significant increase in basement membrane $(p<0.001)$ and endothelial cell $(p<0.001)$ area and a significant teduction in luminal area $(p<0.001)$. There was no significant difference in endothelial cell profile number between endoneurial and epineurial capillaries amongst diabetic patients. Previous studies have demonstrated a good correlation between the degree of microangiopathy and measures of neuropathic severity. In the present study in-
\end{abstract}

creased endoneurial capillary basement membrane area was significantly related to reduced peroneal nerve conduction velocity $(p<0.001)$, myelinated fibre density $(p<0.001)$ and elevated vibration $(p<0.05)$ and thermal $(p<0.001)$ perception. Increased endothelial cell area and reduced luminal size were related to a reduced peroneal nerve conduction $(p<0.05, p<0.01$, respectively), reduced myelinated fibre density $(p<0.05, p<0.01)$ and elevated thermal perception $(p<0.05, p<0.001)$. Epineurial capillary basement membrane, endothelial cell and luminal area failed to relate to measures of neuropathic severity. This study has demonstrated more advanced microangiopathy and a more significant relationship to neuropathic severity in endoneurial compared with epineurial capillaries, thus providing further support for the role of microangiopathy in the pathogenesis of human diabetic neuropathy.

Key words: Diabetes mellitus, microangiopathy, peripheral neuropathy.
Evidence for a role of microvascular disease in the pathogenesis of human diabetic neuropathy is now considerable $[1,2]$. Both earlier qualitative and more recent quantitative studies have demonstrated a wide range of abnormalities which include basement membrane thickening, endothelial cell hypertrophy and hyperplasia with vessel closure [3-10]. Such changes, when accompanied by haemorheological abnormalities [11, 12], may well result in the endoneurial hypoxia which has been demonstrated in patients with severe human diabetic neuropathy [13]. Hypoxia in turn may result in the development and progression of neuropathy $[14,15]$.

Diabetic microangiopathy has also been demonstrated in other tissues affected by long-term complications, namely, retina [16] and kidney [17]. Moreover, a number of studies have shown microangiopathy in muscle $[18,19]$ and skin [20] capillaries suggesting that this may reflect the extent of microangiopathy in the complicated tissues.
However, our recent study demonstrated more advanced microvascular pathology in the sural nerve when compared with muscle and skin capillaries from the same diabetic patients [2]. Furthermore renal tubular basement membrane thickness has been shown to be significantly greater than muscle capillary basement membrane thickness from the same diabetic patient [21]. Therefore the most severe microvascular abnormalities are to be found in those tissues affected by the specific complications of diabetes. Three vascular beds supply the peripheral nerve namely, epineurial, perineurial and endoneurial capillaries [22]. However, nerve fibre damage occurs in the endoneurium $[23,24]$. It was therefore considered important to assess the extent of microvessel abnormalities of endoneurial capillaries which lie in close association with nerve fibres when compared with epineurial capillaries which lie outside the endoneurium separated by the perineurium. These studies may provide further insight into the inti- 

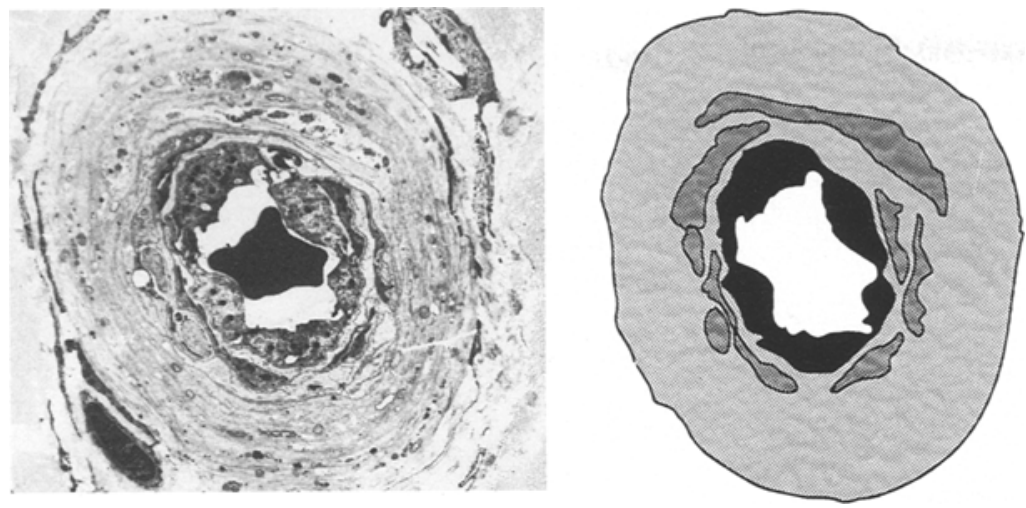

Fig. 1. Electron micrograph $(\times 3000)$ and outline of endoneurial capillary displaying morphometric parameters assessed. Basement membrane area 7 . Pericyte profile 壾; luminal area $\square$; endothelial cell area

mate role of microangiopathy in the pathogenesis of human diabetic neuropathy.

\section{Subjects and methods}

\section{Clinical assessment and electrophysiology}

The studies were performed with the approval of the Manchester Central Hospitals and Royal Hallamshire hospital NHS trusts ethical committees. Informed consent was obtained from each patient prior to the study.

Twenty diabetic patients aged 53 [45-65] (median [interquartile range]) years with neuropathy took part in the study. Inclusion criteria were:

(1) Type 1 (insulin-dependent) or Type 2 (non-insulin-dependent) diabetes for more than 6 months.

(2) Peroneal nerve motor conduction velocity (MCV) below the 5 th centile for age-related reference values for healthy subjects but greater than $30 \mathrm{~ms}^{-1}$.

(3) Vibration perception threshold over the medial malleolus greater than the 95 th centile for age-related healthy subjects, but less than 45 volts [24].

Patients with peripheral vascular disease, renal disease (serum creatinine $>130 \mu \mathrm{mol} / \mathrm{l}$ ), or any other conditions known to cause neuropathy were excluded. Control data for measures of neuropathic severity was obtained from 46 age-matched (58 [34.5-74.6] years) subjects who were either healthy volunteers or hospital patients.

All patients underwent a full history and neurological examination. Peroneal nerve motor conduction velocity (MCV) was assessed using surface electrodes and a Medelec MD92A electrophysiological system (Medelec Ltd., Old Woking, Surrey, UK) in a room at $25^{\circ} \mathrm{C}$. The peroneal nerve $\mathrm{MCV}$ was considered to be a sensitive indicator of sural nerve pathology as a number of previous studies have demonstrated a significant correlation between this measure and sural nerve myelinated fibre density in diabetic patients with both mild [25] and severe [2] neuropathy. Vibration perception threshold was assessed over the great toe using a biothesiometer (Bio-Medical Instrument Company, Newbury, Ohio, USA). Thermal perception was assessed over the dorsum of the foot using a thermoaesthesiometer (Free University Hospital, Amsterdam, The Netherlands).

\section{Nerve Biopsy}

Diabetic patients underwent biopsy of the sural nerve behind the lateral malleolus under $2 \%$ lignocaine local anaesthesia. Non-diabetic control sural nerve was obtained from brain dead multiple organ transplant donors and traumatic amputees, aged 45 [21.8-63.8] years, in whom neurophysiological investigations were not feasible at the time of study. The tissue was fixed primarily in glutaraldehyde in cacodylate buffer and secondarily in osmium tetroxide. After dehydration in a graded series of ethanol, the tissue was embedded in epon resin with propylene oxide as an intermediary. Ultrathin sections were prepared and stained with methanolic uranyl acetate and lead citrate for detailed electron microscopy.

\section{Morphometry}

Electron micrographs $(\times 10000)$ of endoneurial and epineurial capillaries were prepared according to the morphological criteria for capillaries [26].

Exclusion criteria were based on:

(a) More than 8 endothelial cell profiles per capillary.

(b) Microvessel major to minor axis ratio greater than 3:1.

(c) Vessel wall characteristics: 1) presence of elastin; 2) presence of smooth muscle cells as opposed to pericytes found in capillaries. Smooth muscle was characterised by: 1) wider profiles than pericytes; 2) the presence of numerous dense bodies and myofilaments which were less developed in pericytes; 3 ) clustering of mitochondria and ribosomes which were more dispersed in pericytes; 4) more numerous pinocytic vesicles on the cell surface of smooth muscle;5) continuity of the cell layer around the endothelium which was characteristically discontinuous for pericytes.

For the purpose of morphometric assessment the following parameters were measured: perimeter of the lumen (inner border of endothelial cells), perimeter of the outer border of the endothelial cells, perimeter of the outer border of the basement membrane. These were transformed to luminal, endothelial cell and basement membrane area by employing the DIGIT digitising pad interfaced to a BBC microcomputer [27] (Fig. 1). The number of endothelial cell profiles were assessed directly by counting the number of endothelial intercellular junctions in each capillary. Myelinated fibre density was assessed according to previously described techniques [2].

\section{Statistical analysis}

All the results were analysed using Minitab Software (Minitab Inc., State College, Pa., USA). All data is presented as the median and interquartile range and compared using the two tailed Mann-Whitney $\mathrm{U}$-test and Spearmans rank correlation.

\section{Results}

Clinical details and measures of neuropathic severity are presented in Table 1. There was no significant difference in age between the diabetic patients and control subjects. Nine patients had Type 1 diabetes. Peroneal nerve motor conduction velocity (MCV) was significantly reduced 
Table 1. Clinical details and measures of neuropathic severity in diabetic patients $(n=20)$ expressed as median (interquartile range), percentage abnormal and degree of significant difference when compared with control subjects

\begin{tabular}{|c|c|c|}
\hline & Diabetic patients & $\%$ Abnormal \\
\hline Age (years) & $53[45-65]$ & \\
\hline Duration diabetes (years) & $12.5[8.3-15.8]$ & \\
\hline $\mathrm{HbA}_{\mathrm{lc}}(\%)$ & $10.8[9.7-12.3]$ & \\
\hline $\operatorname{PNMCV}\left(\mathrm{ms}^{-1}\right)$ & $36.1[29.8-37.7]^{\mathrm{a}}$ & 100 \\
\hline VPT (volts) & $27[20.3-41.5]^{\mathrm{b}}$ & 100 \\
\hline $\operatorname{TDT}\left({ }^{\circ} \mathrm{C}\right)$ & $5.6[0.4-21.0]^{\mathrm{a}}$ & 75 \\
\hline $\operatorname{MFD}\left(\right.$ no. $\left.\mathrm{mm}^{-2}\right)$ & $2558[1530-5027]^{\mathrm{b}}$ & 100 \\
\hline
\end{tabular}

${ }^{\mathrm{a}} p<0.01,{ }^{\mathrm{b}} p<0.001$

PNMCV, peroneal nerve motor conduction velocity; VPT, vibration perception threshold; TDT, thermal discrimination threshold; MFD, myelinated fibre density. Normal control values $(n=46)$ (PNMCV: 47.5 (43.2-50.1), VPT: 12.8 (8.5-13.7), TDT: 1.0 (0.5-1.3), MFD $\left.(n=10) 6570(5680-7395) \mathrm{HbA}_{1 \mathrm{c}}:<8.0 \%\right)$

$(p<0.01)$ and both vibration $(p<0.001)$ and thermal $(p<0.01)$ perception were elevated in diabetic patients. Myelinated fibre density was significantly reduced in diabetic patients $(p<0.001)$.

\section{Microangiopathy: control vs diabetic patients (Fig.2)}

Results of microvascular pathology are presented in Table 2. Endoneurial basement membrane area $(p<0.001)$, endothelial cell area $(p<0.01)$ and endo- thelial cell profile number $(p<0.001)$ were significantly increased and luminal area $(p<0.001)$ was significantly reduced in diabetic patients when compared with control subjects. In epineurial capillaries both basement membrane area $(p<0.02)$ and endothelial cell profile number $(p<0.001)$ were significantly increased in diabetic patients when compared with control subjects.

\section{Endoneurial vs epineurial capillaries (Fig. 2, Table 2)}

In control subjects no morphological measure of microangiopathy differed significantly between endoneurial and epineurial capillaries. In contrast endoneurial capillaries from diabetic patients demonstrated significantly increased basement membrane area $(p<0.001)$, endothelial cell area $(p<0.001)$ and significantly reduced luminal area $(p<0.001)$ when compared with epineurial capillaries. Endothelial cell profile number did not differ significantly between endoneurial and epineurial capillaries of diabetic patients but was significantly greater in both groups of diabetic capillaries when compared with control subjects $(p<0.001)$. Endoneurial capillary basement membrane area, endothelial cell area and luminal area failed to relate to epineurial capillary basement membrane area, endothelial cell area and luminal area, respectively. However, endothelial cell profile number of endoneurial capillaries was significantly related to endothelial cell profile number of epineurial capillaries $(p<0.05)$.
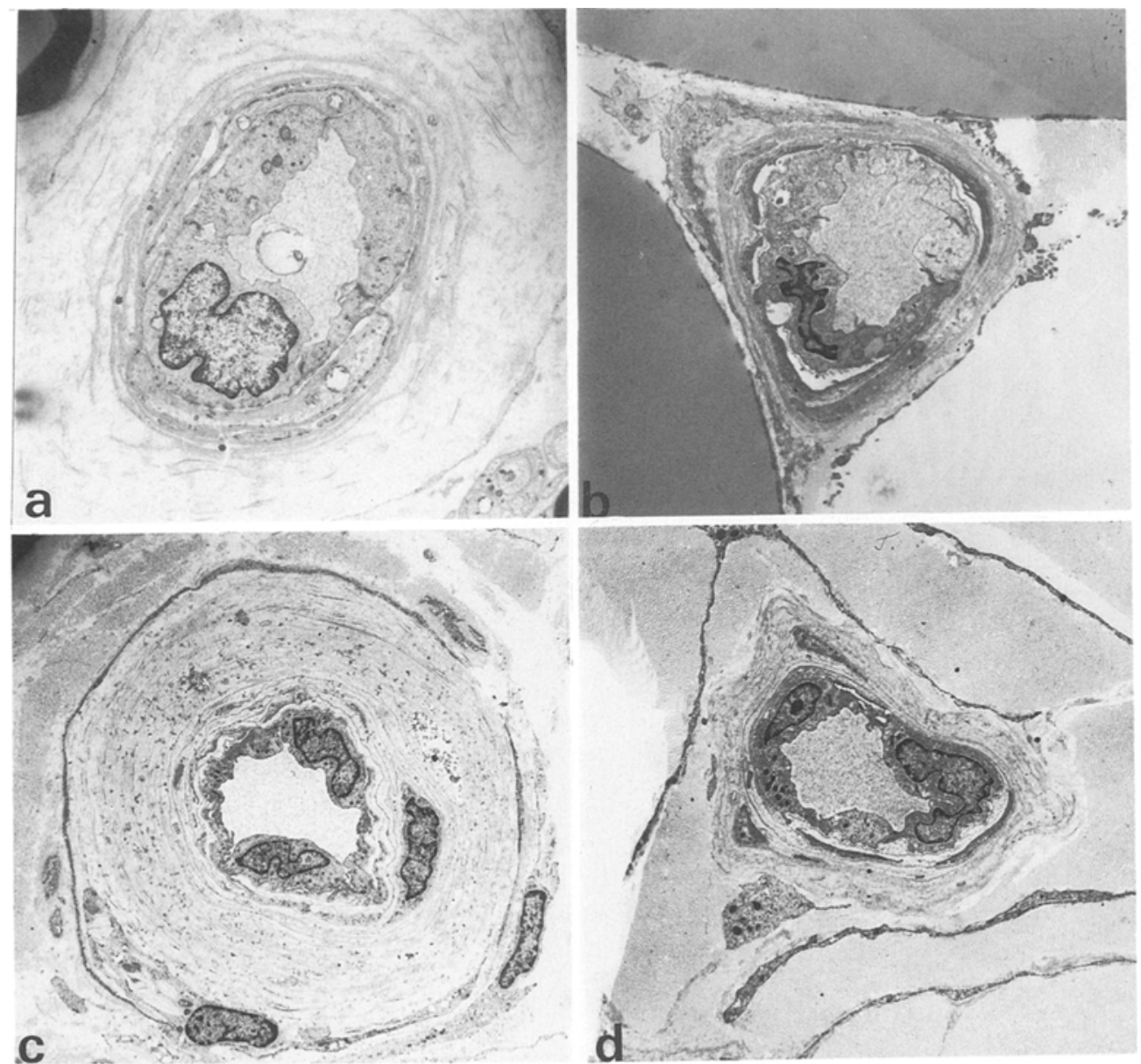

Fig. 2(a-d). Electron micrographs of endoneurial (a) and epineurial (b) capillaries $(\times 3000)$ from a control subject aged 45 and endoneurial (c) and epineurial (d) capillaries $(\times 2500)$ from a 56 -year-old diabetic patient with chronic sensory motor neuropathy displaying morphological abnormalities between control and diabetic capillaries and between diabetic epineurial and endoneurial capillaries 
Table 2. Morphometric data of endoneurial and epineurial capillaries in control subjects and diabetic patients presented as median (interquartile range) and degree of significant difference between groups

\begin{tabular}{|c|c|c|c|c|c|c|c|c|}
\hline & $\begin{array}{l}\text { Control } \\
\text { endoneurium } \\
\text { (A) }\end{array}$ & $\begin{array}{l}\text { Control } \\
\text { epineurium } \\
\text { (B) }\end{array}$ & $\begin{array}{l}\text { Diabetic } \\
\text { endoneurium } \\
\text { (C) }\end{array}$ & $\begin{array}{l}\text { Diabetic } \\
\text { epineurium } \\
\text { (D) }\end{array}$ & Avs B & C vs D & A vs $C$ & B vs D \\
\hline $\begin{array}{l}\text { Basement } \\
\text { membrane area } \\
\left(\mu \mathrm{m}^{2}\right)\end{array}$ & $\begin{array}{l}59.5 \\
(50.5-63.0)\end{array}$ & $\begin{array}{l}51.0 \\
(49.2-59.3)\end{array}$ & $\begin{array}{l}85.6 \\
(76.6-96.1)\end{array}$ & $\begin{array}{l}62.1 \\
(55.9-67.2)\end{array}$ & NS & $p<0.0001$ & $p<0.0001$ & $p<0.02$ \\
\hline $\begin{array}{l}\text { Endothelial } \\
\text { cell area } \\
\left(\mu \mathrm{m}^{2}\right)\end{array}$ & $\begin{array}{l}35.0 \\
(30.7-41.8)\end{array}$ & $\begin{array}{l}31.6 \\
(25.6-36.1)\end{array}$ & $\begin{array}{l}50.5 \\
(40.0-61.1)\end{array}$ & $\begin{array}{l}29.6 \\
(25.0-39.7)\end{array}$ & NS & $p<0.0001$ & $p<0.01$ & NS \\
\hline $\begin{array}{l}\text { Luminal area } \\
\left(\mu \mathrm{m}^{2}\right)\end{array}$ & $\begin{array}{l}34.4 \\
(32.7-39.4)\end{array}$ & $\begin{array}{l}34.7 \\
(32.1-35.6)\end{array}$ & $\begin{array}{l}19.1 \\
(12.6-26.3)\end{array}$ & $\begin{array}{l}31.9 \\
(26.9-35.7)\end{array}$ & NS & $p<0.0001$ & $p<0.0001$ & NS \\
\hline $\begin{array}{l}\text { Endothelial } \\
\text { cell profile } \\
\text { (no.) }\end{array}$ & $\begin{array}{l}3.6 \\
(3.1-4.0)\end{array}$ & $\begin{array}{c}3.7 \\
(3.4-4.1)\end{array}$ & $\begin{array}{l}5.4 \\
(4.9-6.2)\end{array}$ & $\begin{array}{c}5.3 \\
(4.2-5.7)\end{array}$ & NS & NS & $p<0.0001$ & $p<0.001$ \\
\hline
\end{tabular}

Table 3. Correlation between abnormalities in endoneurial (Endo) and epineurial (Epi) capillaries and measures of neuropathic severity expressed as the Spearmans rank correlation coefficient $(r)$ and degree of significance

\begin{tabular}{|c|c|c|c|c|}
\hline & PMNCV & VPT & TDT & MFD \\
\hline \multicolumn{5}{|c|}{ Basement membrane area } \\
\hline $\begin{array}{l}\text { Endo } \\
\text { Epi }\end{array}$ & $\begin{array}{l}r=-0.67, p<0.001 \\
r=0.05, \mathrm{NS}\end{array}$ & $\begin{array}{l}r=0.46, p<0.05 \\
r=0.03, \mathrm{NS}\end{array}$ & $\begin{array}{l}r=0.70, p<0.001 \\
r=-0.03, \mathrm{NS}\end{array}$ & $\begin{array}{l}r=-0.91, p<0.001 \\
r=-0.21, \mathrm{NS}\end{array}$ \\
\hline \multicolumn{5}{|c|}{ Endothelial cell area } \\
\hline $\begin{array}{l}\text { Endo } \\
\text { Epi }\end{array}$ & $\begin{array}{l}r=-0.46, p<0.05 \\
r=0.01, \mathrm{NS}\end{array}$ & $\begin{array}{l}r=0.31, \mathrm{NS} \\
r=\quad 0.02, \mathrm{NS}\end{array}$ & $\begin{array}{l}r=0.46, p<0.05 \\
r=0.09, \mathrm{NS}\end{array}$ & $\begin{array}{l}r=-0.47, p<0.05 \\
r=-0.19, \mathrm{NS}\end{array}$ \\
\hline $\begin{array}{l}\text { Endo } \\
\text { Epi }\end{array}$ & $\begin{array}{ll}r= & 0.55, p<0.01 \\
r= & 0.08, \mathrm{NS}\end{array}$ & $\begin{array}{l}r=-0.41, \mathrm{NS} \\
r=0.05, \mathrm{NS}\end{array}$ & $\begin{array}{l}r=-0.62, p<0.001 \\
r=-0.12, \mathrm{NS}\end{array}$ & $\begin{array}{ll}r= & 0.61, p<0.01 \\
r= & 0.34, \mathrm{NS}\end{array}$ \\
\hline \multicolumn{5}{|c|}{ Endothelial cell profile number } \\
\hline $\begin{array}{l}\text { Endo } \\
\text { Epi }\end{array}$ & $\begin{array}{l}r=-0.32, \mathrm{NS} \\
r=-0.54, p<0.01\end{array}$ & $\begin{array}{l}r=0.18, \mathrm{NS} \\
r=0.38, \mathrm{NS}\end{array}$ & $\begin{array}{l}r=0.34, \mathrm{NS} \\
r=0.50, p<0.02\end{array}$ & $\begin{array}{l}r=-0.27, \mathrm{NS} \\
r=-0.37, \mathrm{NS}\end{array}$ \\
\hline
\end{tabular}

PMNCV, Peroneal motor nerve conduction velocity; VPT, vibration perception threshold; TDT, thermal discrimination threshold; MFD, myelinated fibre density

\section{Correlation between clinical details, microangiopathy and neuropathic severity (Table 3)}

Only endothelial cell area was related to age $(r=0.51$, $p<0.02)$ and the level of $\mathrm{HbA}_{1 \mathrm{c}}(r=-0.48, p<0.05)$. All other endoneurial and epineurial capillary abnormalities failed to relate to age, duration of diabetes or $\mathrm{HbA}_{1 c}$ levels. Increased endoneurial capillary basement membrane area was related to reduced, peroneal nerve $\mathrm{MCV}$ $(p<0.001)$, myelinated fibre density $(p<0.001)$ and elevated vibration $(p<0.05)$ and thermal $(p<0.001)$ perception. An increase in endothelial cell area was related to both reduced peroneal nerve MCV $(p<0.05)$, reduced myelinated fibre density $(p<0.05)$ and elevated thermal perception $(p<0.05)$. Conversely a reduction in luminal area was related to reduced peroneal nerve $\mathrm{MCV}$ $(p<0.01)$, myelinated fibre density $(p<0.01)$ and elevated thermal perception $(p<0.001)$. Endoneurial capillary endothelial cell profile number failed to relate to any of the measures of neuropathic severity. Epineurial capillary basement membrane area, endothelial cell area and luminal area failed to relate to any of the measures of neuropathic severity. Only epineurial capillary endothelial cell profile number was related to reduced peroneal nerve MCV $(p<0.01)$ and elevated thermal perception $(p<0.02)$.

\section{Discussion}

The present study has demonstrated a significant endoneurial microangiopathy in the form of basement membrane thickening, endothelial cell hypertrophy and hyperplasia with luminal narrowing in diabetic patients with neuropathy when compared with normal control subjects, confirming previous findings [2-10]. In addition diabetic patients displayed epineurial capillary abnormalities in the form of basement membrane thickening and endothelial cell hyperplasia.

However, most importantly the present study has shown significantly more pathology in endoneurial capillaries in comparison to epineurial capillaries, particularly in the form of basement membrane thickening, endothelial cell hypertrophy and luminal narrowing. Furthermore 
endoneurial capillary abnormalities were significantly related to both neurophysiological and morphological measures of neuropathic severity in the absence of any relationship between epineurial capillary abnormalities and neuropathic severity. We have previously shown both a more advanced microangiopathy and a stronger relationship to neuropathic severity in endoneurial capillaries when compared with muscle and skin capillaries from the same diabetic patients [2]. Renal tubules also displayed more severe basement membrane thickening than muscle capillaries from the same diabetic patients [21]. Moreover, in a recent study of the sural nerve no relationship was observed between epineurial arteriolar abnormalities and neuropathic severity [28], in the presence of a strong relationship between endoneurial capillary abnormalities and neuropathic severity in the same diabetic patients $[7,8]$. Therefore, these studies suggest that more advanced microvascular disease occurs in the tissues most affected by the diabetic complications, particularly at the site of the most advanced pathology.

Considering the abnormality of basement membrane thickening, a number of mechanisms are likely to underlie this change $[8,19,21]$. However, the more significant basement membrane thickening of endoneurial compared with epineural capillaries would suggest that only part of these mechanisms are expressed in the epineurium or that the endoneurial environment provides optimal expression of such abnormalities. Basement membrane thickening may compromise, not only microvascular compliance $[29,30]$ and function [31] but may damage the endothelium via an increased shear stress [32].

One pathological abnormality which is common to both groups of diabetic capillaries is that of endothelial cell hyperplasia which may be caused by a number of factors including ischaemia [33] and physical-chemical stress $[32,34]$. This finding suggests that the mechanisms causing endothelial cell hyperplasia may differ from those which cause basement membrane thickening and endothelial cell hypertrophy. A discordant pattern of cellular (endothelial cell) and matrix (basement membrane) abnormalities have been demonstrated previously in the renal vasculature [17]. Furthermore, an improvement of glycaemic control reduces renal basement membrane thickening [35] in the absence of any change in cellular mesangial structure [36]. Pericyte cell loss is the pathological hallmark of diabetic retinopathy [37]. However, previous studies in endoneurial capillaries have demonstrated either no change $[9,10,38]$ or conversely an increase in the pericyte profile number $[2,8,39]$. The pathogenetic relevance of pericyte cell abnormalities in endoneurial microangiopathy is therefore debatable and was therefore not assessed in the present study.

The effect of age and duration of diabetes on all these abnormalities has been considered to be important [38], but the presentstudy in agreement with previousstudies [2, 7-10] failed to find any relationship with these variables.

Recent studies have shown an increased blood flow in nailfold capillaries [40] and the retina [37] of diabetic patients, with an accompanying increase in vessel luminal area [37]. The presence of an increased capillary luminal size in endoneurial capillaries of patients without [8] or with mild [39] neuropathy would also suggest an increased flow at an early stage of neuropathy. However, as pathology progresses, blood flow is compromised due to endothelial cell hyperplasia and hypertrophy with luminal narrowing and reduced vessel compliance due to basement membrane thickening. These abnormalities may result in a reduced endoneurial capillary oxygen diffusing capacity [2] and endoneurial hypoxia in patients with established diabetic neuropathy [13]. A relationship between nerve function and transcutaneous oxygen tension [41], the inability to improve nerve conduction on exercise [42] and neuropathy in hypoxic patients with chronic obstructive airways disease [15] provide strong evidence for the role of hypoxia in the development of human diabeticneuropathy.

The present study has demonstrated significant correlations between morphometric measures of microangiopathy and neuropathic severity assessed by both functional and pathological means. It is not, of course, possible to directly relate microangiopathy in the pathogenesis of human diabetic neuropathy. However, this study has shown that endoneurial tissue is the most important site for assessing factors in the pathogenesis of neuropathy, and therapies to prevent and perhaps reverse microangiopathy and neuropathy must be aimed at having an optimal effect in the endoneurium. Therefore, the isolation of more advanced microangiopathy to the site of nerve damage, namely the endoneurium, further strengthens the evidence for the role of microangiopathy in the pathogenesis of human diabetic neuropathy.

\section{References}

1. Dyck PJ (1989) Hypoxic neuropathy: does hypoxia play a role in diabetic neuropathy? Neurology 39: 111-118

2. Malik RA, Newrick PG, Sharma AK et al. (1989) Microangiopathy in human diabetic neuropathy: relationship between capillary abnormalities and the severity of neuropathy. Diabetologia 32: $92-102$

3. Fagerberg SE (1959) Diabetic neuropathy: a clinical and histological study on the significance of vascular affections. Acta Med Scand 164 [Suppl 345]: 1-109

4. Williams E, Timperley WR, Ward JD, Duckworth T (1980) Electronmicroscopical studies of vessels in diabetic peripheral neuropathy. J Clin Path 33: 462-470

5. Timperley WR, Boulton AIM, Davies-Jones GAB, Jarratt JA, Ward JD (1985) Small vessel disease in progressive diabetic neuropathy associated with good metabolic control. I Clin Path 38: $1030-1038$

6. Powell HC, Rosoff J, Myers RR (1985) Microangiopathy in human diabetic neuropathy. Acta Neuropathol (Berl) 68: 295305

7. Dyck PJ, Hansen S, Karnes J et al. (1985) Capillary number and percentage closed in human diabetic sural nerve. Proc Natl Acad Sci USA 82: 2513-2517

8. Yasuda H, Dyck PJ (1987) Abnormalities of endoneurial microvessels and sural nerve pathology in diabetic neuropathy. Neurology 37:20-28

9. Britland ST, Young RJ, Sharma AK, Clarke BF (1990) Relationship of endoneurial capillary abnormalities to type and severity of diabetic polyneuropathy. Diabetes 39: 909-913

10. Bradley I, Thomas PK, King RHM, Llewellyn IG, Muddle JR, Watkins PJ (1990) Morphometry of endoneurial capillaries in diabetic sensory and autonomic neuropathy. Diabetologia 33: $611-618$ 
11. Simpson LO (1988) Altered blood theology in the pathogenesis of diabetic and other neuropathy. Muscle Nerve 2: 725-744

12. Ford I, Malik RA, Newrick PG, Preston FE, Ward JD, Greaves M (1992) Relationship between haemostatic factors and capillary morphology in human diabetic neuropathy. Thromb Haemost 68: 628-633

13. Newrick PG, Wilson AJ, Jakubowski J, Boulton AJM, Ward JD (1986) Sural nerve oxygen tension in diabetes. Br Med J 193: 1053-1054

14. Low PA, Tuck RR, Takeuchi M (1987) Nerve microenvironment in diabetic neuropathy. In: Dyck PJ, Thomas PK, Asbury AK, Winegrad AI, Porte D (eds) Diabetic neuropathy. Saunders, Philadelphia, pp 266-278

15. Malik RA, Masson EA, Sharma AK et al. (1990) Hypoxic neuropathy: relevance to human diabetic neuropathy. Diabetologia 33: 311-318

16. Ramsay RC, Goetz FC, Sutherland DER et al. (1988) Progression of diabetic retinopathy after pancreas transplantation for insulin dependent diabetes mellitus. N Engl J Med 318:208-214

17. Osterby R (1992) Glomerular structural changes in type 1 (insulin-dependent) diabetes mellitus: causes, consequences, and prevention. Diabetologia 35: 803-812

18. Sosenko JM, Miettinen OS, Williamson JR, Gabbay KH (1984) Muscle capillary basement membrane thickness and long term glycaemia in type 1 diabetes mellitus. N Engl J Med 311:694-698

19. Tilton RG, Hoffman PL, Kilo C, Williamson JR (1981) Pericyte degeneration and basement membrane thickening in skeletal muscle capillaries of human diabetic patients. Diabetes 30 : 326334

20. Ajjam ZA, Barton S, Corbett M, Owens D, Marks R (1985) Quantitative evaluation of dermal vasculature in diabetics. Q J Med 215:229-239

21. Vracko R, Pecararo RE, Carter WB (1980) Overview article: basal lamina of epidermis, muscle fibres, muscle capillaries, and renal tubules: changes with ageing and diabetes mellitus. Ultrastruct Pathol 1: 559-574

22. Sunderland S (1990) The anatomy and physiology of nerve injury. Muscle Nerve 13: 771-784

23. Behse F, Bucthal F, Carlsen F (1977) Nerve biopsy and conduction studies in diabetic neuropathy. J Neurol Neurosurg Psychiatry 40: 1072-1082

24. Dyck PJ, Karnes JL, Daube J et al. (1985) Clinical and neuropathologic criteria for the diagnosis and staging of diabetic neuropathy. Brain 108: 861-880

25. Veves A, Malik RA, Lye RH et al. (1991) The relationship between sural nerve morphometric findings and measures of peripheral nerve function in mild diabetic neuropathy. Diabetic Med 8: 917-921

26. Bell MA, Weddell AGM (1984) A morphometric study of intrafascicular vessels in mammalian sciatic nerve. Muscle Nerve 7: 524-534

27. Hayes BP, Poulsom R, Fitzke FW (1988) Computer measurement of normal and diabetic basement membrane thickness. In: Sakamoto N, Kinoshita JH, Kador PF, Hotta N (eds) Polyol pathway and its role in diabetic complications. Elsevier, Amsterdam, pp 300-305

28. Korthals JK, Gieron MA, Dyck PJ (1988) Intima of epineurial arterioles is increased in diabetic polyneuropathy. Neurology 38 : $1582-1586$
29. Tooke JE (1986) Microvascular haemodynamics in diabetes mellitus. Clin Sci 70: 119-125

30. Oxlund H, Andreassen TT (1992) Aminoguanidine treatment reduces the increase in collagen stability of rats with experimental diabetes. Diabetologia 35:19-25

31. Rayman G, Williams SA, Spencer PD, Smaje LH, Wise PH, Tooke JE (1986) Impaired microvascular hyperaemic response to minor skin trauma in type 1 diabetes. $\mathrm{Br}$ Med J 292: 1295 1298

32. Fry DL (1969) Certain histological and chemical responses of the vascular interface to acutely induced mechanical stress in the aorta of the dog. Circ Res 24: 93-108

33. Stefansson E, Wilson CA, Schoen T, Kuwibara T (1988) Experimental ischaemia induces cell mitosis in the adult rat retina. Invest Opthalmol Visual Sci 29: 1050-1055

34. Deem CW, Futterman S, Kalina RE (1974) Induction of endothelial cell proliferation in rat retinal venules by chemical and indirect physical trauma. Invest Opthalmol 13: 580-585

35. Bilous RW, Mauer SM, Sutherland DER, Najarian JS, Goetz FC, Steffes MW (1989) The effects of pancreas transplantation on the glomerular structure of renal allografts in patients with insulin-dependent diabetes. N Engl J Med 321: 80-85

36. Steffes MW, Osterby R, Chavers B, Mauer SM (1989) Mesangial expansion as a central mechanism for loss of kidney function in diabetic patients. Diabetes 38: 1077-1081

37. Patel V, Rassam S, Newsom R, Wick J, Kohner E (1992) Retinal blood flow in diabetic retinopathy. Br Med J 305: 678-683

38. Sima AAF, Nathaniel V, Prashar A, Bril V, Greene DA (1991) Endoneurial microvessels in human diabetic neuropathy. Endothelial cell dysjunction and lack of treatment effect by aldose reductase inhibitor. Diabetes 40: 1090-1099

39. Malik RA, Veves A, Masson EA et al. (1992) Endoneurial capillary abnormalities in mild human diabetic neuropathy. J Neurol Neurosurg Psychiatry 55: 557-561

40. Sandeman DD, Shore AC, Tooke JE (1992) Relation of skin capillary pressure in patients with insulin-dependent diabetes mellitus to complications and metabolic control. N Engl J Med 327: 760-764

41. Young MJ, Veves A, Walker MG, Boulton AJM (1992) Correlations between nerve function and tissue oxygenation in diabetic patients: further clues to the aetiology of diabetic neuropathy? Diabetologia 35: 1146-1150

42. Tesfaye S, Harris ND, Wilson RM, Ward JD (1992) Exercise-induced conduction velocity increment: a marker of impaired peripheral nerve blood flow in diabetic neuropathy. Diabetologia 35: $155-159$

Received: 11 November 1992

and in revised form: 11 January 1993

Dr. R.A.Malik

Department of Medicine (Diabetes)

Manchester Royal Infirmary

Oxford Road

Manchester M13 9WL

UK 